\title{
Konsentrasi Anion Di Udara Ambien Dan Analisis Lintasan Balik Sumber Polutan Di Kota Semarang
}

\author{
Haryono S Huboyo ${ }^{1 *}$, Mochtar Hadiwidodo ${ }^{2}$, Mochamad Nurihsan ${ }^{3}$ \\ Departemen Teknik Lingkungan Fakultas Teknik Universitas Diponegoro \\ Jl. Prof. H. Sudarto, SH Tembalang, Semarang, Indonesia 50275 \\ *Koresponden email : huboyo@gmail.com
}

Diterima: 30 September 2020

Disetujui: 8 Oktober 2020

\begin{abstract}
Air pollution in urban areas shows fluctuations in quality due to increasingly complex pollutant sources. This study aimed to determine the content of water soluble anions and sources of dust pollutants using the back trajectory method. Air quality dust was taken at the end of 2019 in Pedurungan District and Gunungpati District in Semarang City for 2 days with a dust measuring device at each sample point. From each sample, a laboratory test was carried out on its anion content. Anions were analyzed at the Diponegoro University Integrated Laboratory by ion chromatography. The dust concentration ranges from $60-90 \mu \mathrm{g} / \mathrm{Nm} 3$ with anion content below 25\%. Some of the dominant anions are thought to come from industrial activities such as burning coal and densely populated areas in the city of Semarang. Based on the results of the trace back from the origin of the dust, it can be seen that the dust comes from the south area (Genuk area). Therefore, air pollution mitigation is directed to the South, where the potential comes from industrial activities and vehicles.
\end{abstract}

Keywords: air pollution, dust, trajectory, sources, south

\begin{abstract}
Abstrak
Pencemaran udara di kawasan perkotaan menunjukkan fluktuasi kualitas karena sumber pencemar yang makin kompleks. Studi ini ditujukan untuk mengetahui kandungan water soluble anions dan sumber polutan debu dengan metode runut balik (back trajectories). Kualitas udara debu diambil pada akhir Tahun 2019 di Kecamatan Pedurungan dan Kecamatan Gunungpati di Kota Semarang selama 2 hari dengan alat pengukur debu pada masing-masing titik sampel. Pengujian kandungan anion tiap sampel dilakukan di Laboratorium Terpadu Universitas Diponegoro dengan ion kromatografi. Konsentrasi debu berkisar $60-90 \mu \mathrm{g} / \mathrm{Nm}^{3}$ dengan kandungan anion dibawah $25 \%$. Beberapa anion yang dominan diduga berasal dari berasal dari aktivitas industri seperti pembakaran batubara dan kawasan padat penduduk di Kota Semarang. Berdasarkan hasil runutan balik asal debu terlihat debu berasal dari daerah selatan (daerah Genuk). Oleh karena itu, mitigasi polusi udara diarahkan ke daerah Selatan dimana potensinya berasal dari aktivitas industri dan kendaraan.
\end{abstract}

Kata kunci: debu, polusi udara, lintasan, sumber, selatan

\section{Pendahuluan}

Perubahan tata guna lahan dan keberadaan kawasan industri menimbulkan berbagai dampak, baik dampak positif maupun negatif. Kegiatan industri memberikan konstribusi peningkatan konsentrasi polutan seperti gas ke udara bebas di atmosfer. Penggunaan bahan bakar minyak dan batubara di sektor industri dan pembangkit listrik akan mengemisikan $\mathrm{NO}_{2}, \mathrm{SO}_{2}$, dan aerosol $\left\{\left(\mathrm{NH}_{4}\right)_{2} \mathrm{SO}_{4}\right.$ dan $\left.\mathrm{NH}_{4} \mathrm{NO}_{3}\right\}$ ke udara bebas yang akan mempengaruhi keadaan kualitas lingkungan. Sebaran pencemaran di udara dipengaruhi oleh proses transportasi maupun transformasi (reaksi kimiawi) pencemar di atmosfer. Proses transportasi dan transformasi pencemar sangat dipengarui oleh faktor meteorologi, seperti arah dan kecepatan angin, suhu udara, dan kondisi stabilitas atmosfer [1].

Partikel dalam bentuk particulate matter yaitu TSP (Total Suspended Particle) dipengaruhi oleh pembentukan partikel - partikel di dlam atmosfer yang terdiri dari aerosol primer dan aerosol sekunder [2]. Aerosol primer dihasilkan dari sumber langsung seperti kemacetan ataupun debu - debu yang tertiup, sedangkan aerosol sekunder dihasilkan dari reaksi kimia dari fasa gas [3]. Oleh karena itu aerosol atmosfer merupakan salah satu komponen yang penting dalam mengetahui partikel aerosol yang dapat 
menyebarkan dan menyerap radiasi panas matahari yang dipancarkan dari permukaan bumi yang berdampak dalam pembentukkan awan dan reaksi heterogen kimiawi [4].

Sehingga particulate matter atau TSP yang terbentuk ditentukan oleh komponen partikel ion-ion atau disebut dengan water soluble ions yang merupakan komponen kimia utama dalam pembentukan PM atau TSP [5]. Oleh karena itu komponen kimia dari TSP mempunyai peran penting dalam polusi udara terkait dengan dampak yang diberikan seperti perubahan iklim dan kesehatan manusia [6]. Pembentukan partikel-partikel dari water soluble ion tersebut perlu diketahui persebaran dispersi dan lintasannya. Penggunaan model dispersi polutan akan memnantu dalam prediksi sebaran konsentrasi polutan yang diemisikan dari suatu sumber [7]. Sehingga, dapat diprediksi arah lintasan dan konsentrasi polutan yang tersebar di kota Semarang untuk menjadi kebijakan dan arahan untuk mengurangi polutan di wilayah yang memiliki konsentrasi tinggi.

Water soluble ions yang berhubungan dengan TSP ialah $\mathrm{SO}_{4}^{2-}, \mathrm{NO}_{3}{ }^{-}, \mathrm{Cl}^{-}, \mathrm{F}^{-}$untuk anion. Jenisjenis water soluble ions tersebut memiliki formasi dan distribusi ukuran partikel yang berbeda- beda, seperti contohnya formasi dan ukuran partikel dari ialah $\mathrm{SO}_{4}{ }^{2-}$ dan $\mathrm{NO}_{3}{ }^{-}$ditentukan oleh konsentrasi dari $\mathrm{NH}_{4}{ }^{+}$[8]. Dalam penelitian ini juga digunakan model HYSPLIT untuk mengetahui sumber, lintasan dan dispersi polutan [7] .Hybrid Single-Particle Dagrangian Trajectory (HYSPLIT) merupakan salah satu model yang digunakan untuk memprediksi trajektori, disperse dan konsentrasi polutan dari sumber titik, garis, maupun area. Model ini mengaitkan hubungan antara komponen distribusi polutan dengan komponen meteorology untuk mengetahui sumber lokasi. Model HYSPLIT yang digunakan dalam penelitian ini adalah back trajectory analysis atau model lintasan balik untuk mengetahui sumber polutan yang dapat mengetahui hubungan antara sumber dan reseptor, sehingga digunakan simulasinya dalam transport atmosfir, dispersi dan deposisi dari polutan dan material berbahaya.

Dari penjabaran masalah-masalah diatas maka perlu dilakukan analisis konsentrasi terhadap water soluble anion seperti $\mathrm{SO}_{4}{ }^{2-}, \mathrm{NO}_{3}{ }^{-}, \mathrm{Cl}^{-}, \mathrm{F}^{-}, \mathrm{Br}^{-}, \mathrm{PO}_{4}{ }^{3-}$ dalam kontribusinya membentuk TSP sebagai polutan yang berdampak terhadap udara ambien beserta prediksi sumber polutan dan lintasannya untuk mengantisipasi polutan tersebut tersebar di Kota Semarang sehingga menjadi suatu peraturan dan kebijakan dalam mengurangi pencemaran udara.

\section{Metodologi Penelitian}

\section{Tempat dan Waktu Penelitian}

Penelitian ini dilakukan di dua titik di Kota Semarang yaitu Kecamatan Pedurungan pada titik koordinat $07^{\circ} 00^{\prime} 21,62^{\prime \prime}$ LS dan $110^{\circ} 28^{\prime} 23,85^{\prime \prime}$ BT dan Kecamatan Gunungpati pada titik koordinat $07^{\circ}$ 05' 17,12" LS dan $110^{\circ} 23$ '08,60" BT pada tanggal 23 - 28 November 2019 pada musim awal hujan. Pada masing - masing titik sampling dilakukan pengambilan TSP selama 2 hari yang dipilih berdasarkan kepadatan penduduk dan daerah proyeksi di Kota Semarang untuk mengetahui perbandingan konsentrasi dan sumber polutan dari daerah tersebut.

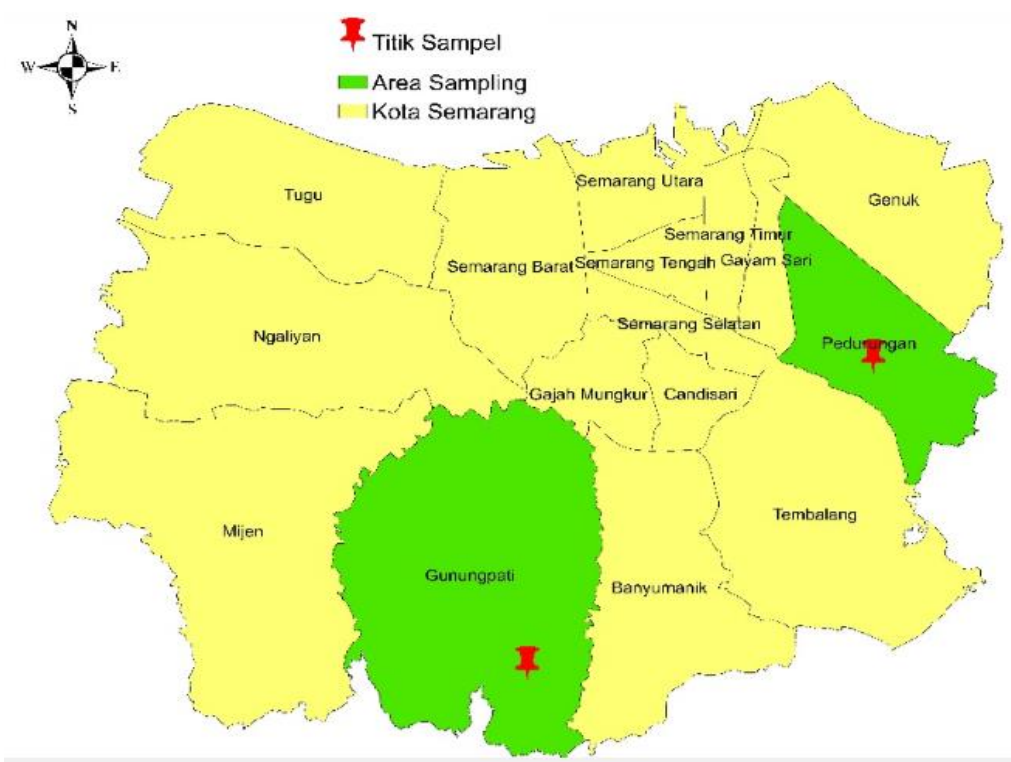

Gambar 1. Lokasi pengukuran di Kota Semarang Sumber: Diolah dari peta di BPS [9] 


\section{Pengambilan dan Pengolahan Sampel}

Pengambilan sampel TSP dilakukan dengan alat HVAS (High Volume Air Sampler) sesuai dengan SNI 7119.3-2017 - Bagian 3: Cara Uji Partikel Tersuspensi Total menggunakan peralatan High Volume Air Sampler. Sedangkan untuk filter yang digunakan ialah jenis EPM 2000 Filter Quartz yang berjenis serat kaca dengan fiber yang kecil, jenis filter ini sudah sering digunakan dalam pengukuran kualitas udara ambien dengan flowrate yang besar. Filter sampling TSP dipanaskan dengan oven pada temperature $95^{\circ} \mathrm{C}$ untuk menghilangkan bahan - bahan organik di dalamnya dan dimasukkan ke dalam plastik zipper untuk melindungi dari kondisi luar filter.

Untuk pengolahan sampel digunakan metode ion chromatography dengan alat Ion Chromatography 2010 (IC-2010) merk Tosoh untuk mengetahui konsentrasi dari water soluble anion, sedangkan untuk preparasi yang digunakan untuk mengubah filter yang berbentuk padatan menjadi cairan dengan alat sonicator yang ditambahkan terlebih dahulu $50 \mathrm{ml}$ aquabides untuk melarutkan lalu didiamkan selama 2 jam. Anion yang terdeteksi pada alat tersebut ialah $\mathrm{SO}_{4}{ }^{2-}, \mathrm{NO}_{3}{ }^{-}, \mathrm{Cl}^{-}, \mathrm{F}^{-}, \mathrm{Br}^{-}, \mathrm{PO}_{4}{ }^{3-}$ mengacu pada Certified Reference Material (CRM) dari Sigma-Aldrich Multi Anion Standart 1 for IC. Namun dalam hasil analisisnya ion $\mathrm{Br}$ dan PO43- tidak terdeteksi di IC jadi tidak dilakukan pembahasan ditahap selanjutnya.

Sementara itu, untuk analisis backward trajectories HYSPLIT dapat diakses pada www.ready.noaa.gov/HYSPLIT dengan trajectory normal, GDAS sebagai data meteorologi dan ketinggian lintasan sumber polutan $50 \mathrm{~m}$ di atas laut. Dengan periode waktu 24 jam balik dengan 5 lintasan baru setiap jamnya untuk memvalidasi lintasan yang dihasilkan dari HYSPLIT.

\section{Hasil dan Pembahasan} Konsentrasi TSP

Konsentrasi yang diperoleh berdasar pengukuran di lapangan dalam satuan $\mu \mathrm{g} / \mathrm{m}^{3}$. Berdasarkan perhitungan konsentrasi TSP didapatkan bahwa konsentrasi pada Kecamatan Pedurungan hari Ke 1 dan 2 lalu Kecamatan Gunungpati hari ke 1 dan 2 secara berturut-turut yaitu $98,902 \mu \mathrm{g} / \mathrm{Nm}^{3}, 80,764 \mu \mathrm{g} / \mathrm{Nm}^{3}$, $59,605 \mu \mathrm{g} / \mathrm{Nm}^{3}$ dan $61,858 \mu \mathrm{g} / \mathrm{Nm}^{3}$.

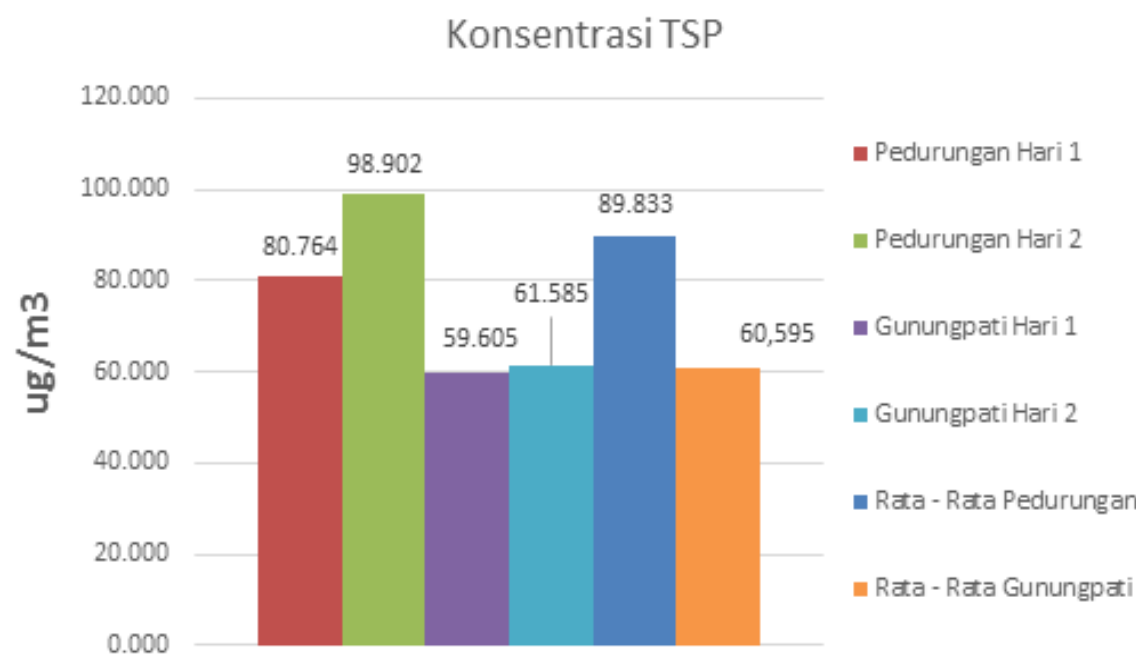

Gambar 2. Konsentrasi TSP di tempat pengukuran Sumber: Analisis penelitian

Sementara ditinjau dari rata - rata Kecamatan Pedurungan dan Kecamatan Gunungpati, didapatkan nilai rata - rata di Kecamatan Pedurungan yaitu $89,833 \mu \mathrm{g} / \mathrm{Nm} 3$ dan di Kecamatan Gunungpati $60,595 \mu \mathrm{g} / \mathrm{Nm}^{3}$. Dari nilai rata- rata ini tidak melebihi baku mutu yang ditentukan Peraturan Pemerintah No 41 Tahun 1999 tentang Pengendalian Pencemaran Udara, batas baku mutu dalam peraturan tersebut ialah $230 \mu \mathrm{g} / \mathrm{Nm}^{3}$. Nilai rata - rata ini merupakan nilai minimum dan maksimum dari konsentrasi TSP di lokasi pengambilan sampel, sehingga nilai konsentrasi TSP yang menjadi acuan yaitu nilai rata - rata konsentrasi TSP dari 2 nilai konsentrasi di lokasi pengambilan sampel. 


\section{Konsentrasi Water Soluble Anion}

\section{a. Kecamatan Pedurungan}

Berdasar Gambar 3 diketahui bahwa kandungan water soluble anion pada udara ambien di Kecamatan Pedurungan hari ke -1 tertinggi ke terendah ialah $\mathrm{SO}_{4}{ }^{2-}>\mathrm{NO}_{3}^{-}>\mathrm{Cl}^{-}>\mathrm{F}^{-}$. Demikian juga pada hari ke-2 memiliki trend yang sama.

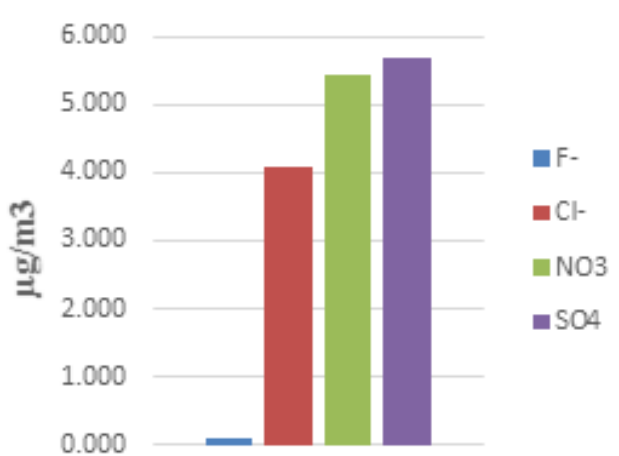

Hari-1

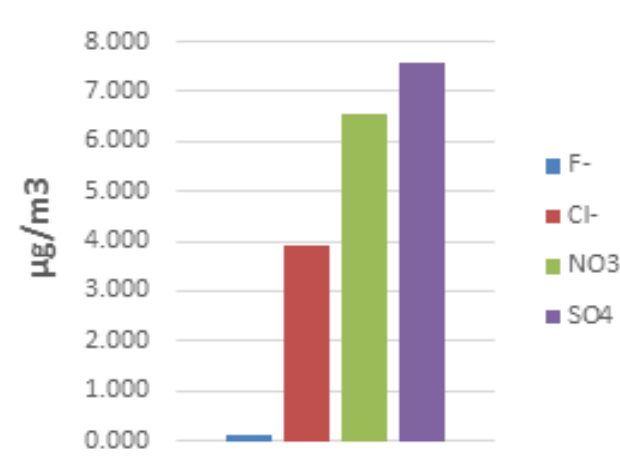

Hari-2

Gambar 3. Konsentrasi Water Soluble Anion di Pedurungan Sumber: Analisis penelitian

Konsentrasi $\mathrm{SO}_{4}{ }^{2-}$ merupakan konsentrasi water soluble anion tertinggi dikarenakan berhubungan dengan tingginya konsentrasi $\mathrm{SO}_{2}$ yang diakibatkan dari konsumsi batu bara dan rendahnya dispersi [10] Water soluble anion jenis $\mathrm{SO}_{4}{ }^{2-}$ dan $\mathrm{NO}_{3-}$ - merupakan anion yang paling tinggi dibandingkan dengan water soluble anion lainnya. Hal ini dikarenakan terdapat hubungan antara komponen tersebut dengan sumber polutan bergerak dan sumber polutan tidak bergerak.

Sedangkan untuk konsentrasi $\mathrm{Cl}^{-}$di Kecamatan Pedurungan dapat dipengaruhi oleh aerosol laut (garam laut) dan pembakaran biomassa termasuk didalamnya aktivitas pembakaran jerami dan penggunaan kembang api. Hal ini sesuai dengan ref. [11] yang menyatakan bahwa salah satu indikator kebakaran biomassa adalah munculnya ion $\mathrm{Cl}^{-}$. Konsentrasi water soluble anion lainnya yaitu $\mathrm{F}^{-}$dapat dihasilkan dari sumber antropogenik yang berasal dari alam seperti erupsi volkanik, debu dari batu batuan, dan lingkungan perairan [12]. Sedangkan untuk konsentrasi water soluble anion jenis $\mathrm{NO}_{3}{ }^{-}$di Kecamatan Pedurungan disebabkan oleh transportasi dengan berbagai jenis kendaraan pribadi ataupun umum.

\section{b. Kecamatan Gunungpati}

Kandungan water soluble anion pada udara ambien di Kecamatan Gunungpati hari ke-1 dari tertinggi ke terendah ialah $\mathrm{SO}_{4}{ }^{2-}>\mathrm{NO}_{3^{-}}>\mathrm{Cl}^{-}>\mathrm{F}^{-}$dengan konsentrasi secara berturut - turut $5,20 \mu \mathrm{g} / \mathrm{m} 3$, $4,95 \mu \mathrm{g} / \mathrm{m} 3,2,29 \mu \mathrm{g} / \mathrm{m} 3,0,059 \mu \mathrm{g} / \mathrm{m} 3$. Tren yang sama juga terjadi pada pengukuran hari ke-2.

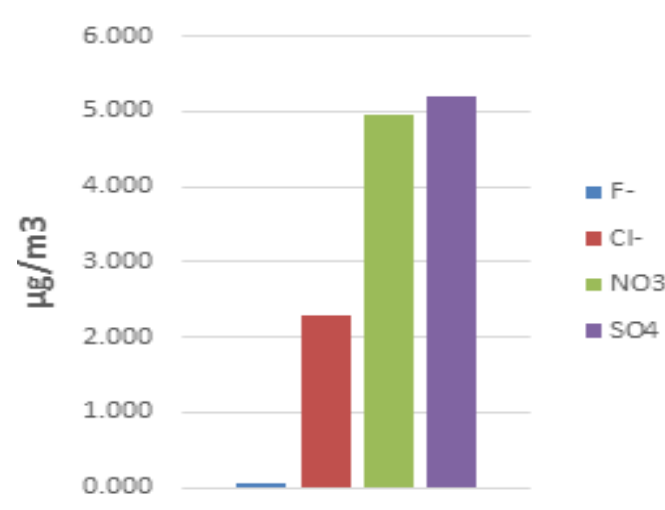

Hari-1

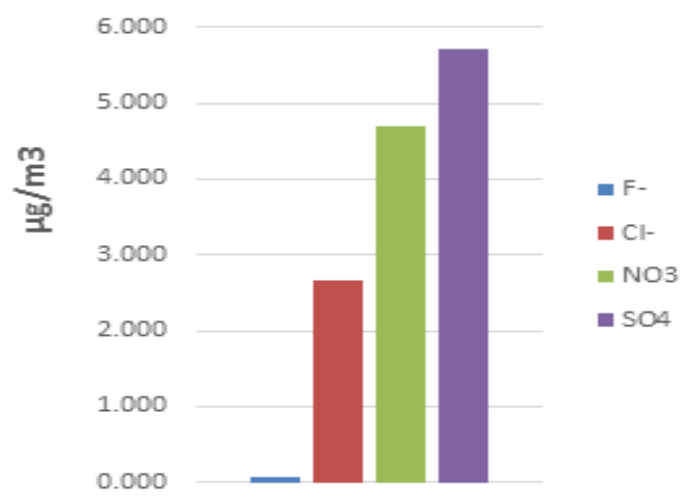

Hari-2

Gambar 4. Konsentrasi Water Soluble Anion di Gunung Pati

Sumber: Analisis penelitian

Konsentrasi $\mathrm{SO}_{4}{ }^{2-}$ masih menjadi konsentrasi water soluble anion yang tinggi di Kecamatan Gunungpati. Dalam penelitian yang dilakukan oleh ref. [13] menyatakan bahwa fraksi $\mathrm{SO}_{2}$ dihasilkan dari reaksi homogen dan heterogen yang teroksidasi menjadi aerosol sulfat sebelum deposisi kering maupun 
basah. Untuk konsentrasi $\mathrm{NO}_{3}^{-}$dipengaruhi oleh nitrat yang merupakan komponen dominan dalam aerosol atmosfir perkotaan, partikulat nitrat bertransformasi melalui photo-oxidation dari $\mathrm{NO}_{2}$ yang berasal dari pembakaran bahan bakar fosil. Sementara untuk $\mathrm{Cl}^{-}$merupakan konsentrasi tertinggi ketiga setelah $\mathrm{SO}_{4}{ }^{2-}$ dan $\mathrm{NO}_{3}{ }^{-}$Konsentrasi $\mathrm{Cl}^{-}$berbentuk dalam butiran halus dan butiran kasar partikel. Sumber tersebut berasal dari partikel yang memiliki ukuran kurang dari $<2.5 \mu \mathrm{m}$ dan berasal dari aerosol laut (aerosol sekunder) dan proses pembakaran.

\section{Prediksi Sumber Polutan dengan Backward Trajectories}

Dalam menganalisis sumber polutan dari titik lokasi pengambilan sampel dilakukan analisis transport jarak jauh massa yang difokuskan terhadap TSP. Model HYSPLIT dapat memodelkan jalur polutan pada kondisi atmosferik tidak stabil yang lemah [14]. Penggunaan HYSPLIT untuk mengindentifikasi potensial sumber polutan beserta dengan lintasan balik dari titik lokasi sampel yaitu Kecamatan Pedurungan dan Kecamatan Gunungpati. Backward trajectories berakhir di titik lokasi pengambilan sampel yang dilakukan selama 24 jam balik dengan ketinggian $50 \mathrm{~m}$ yang merepresentasikan aerosol seperti terlihat pada Gambar $\mathbf{5}$.

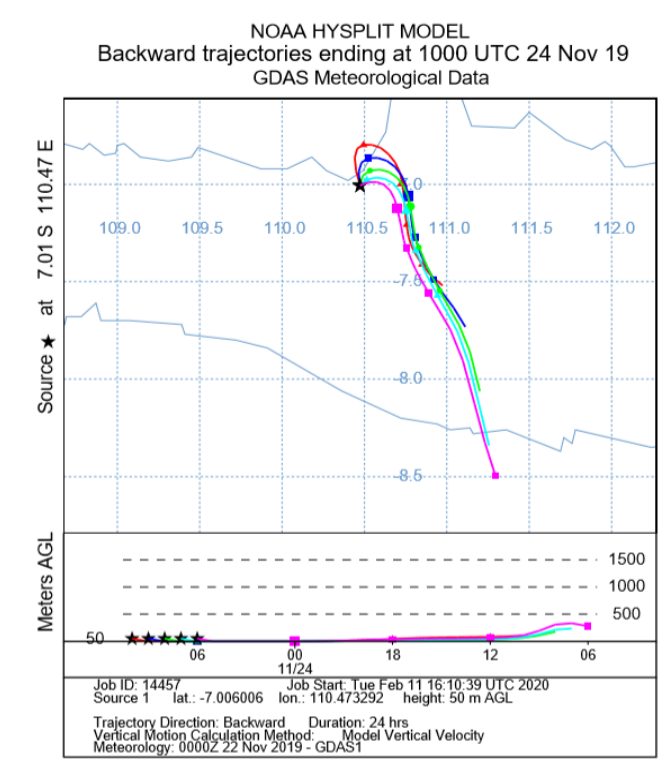

Pedurungan hari-1

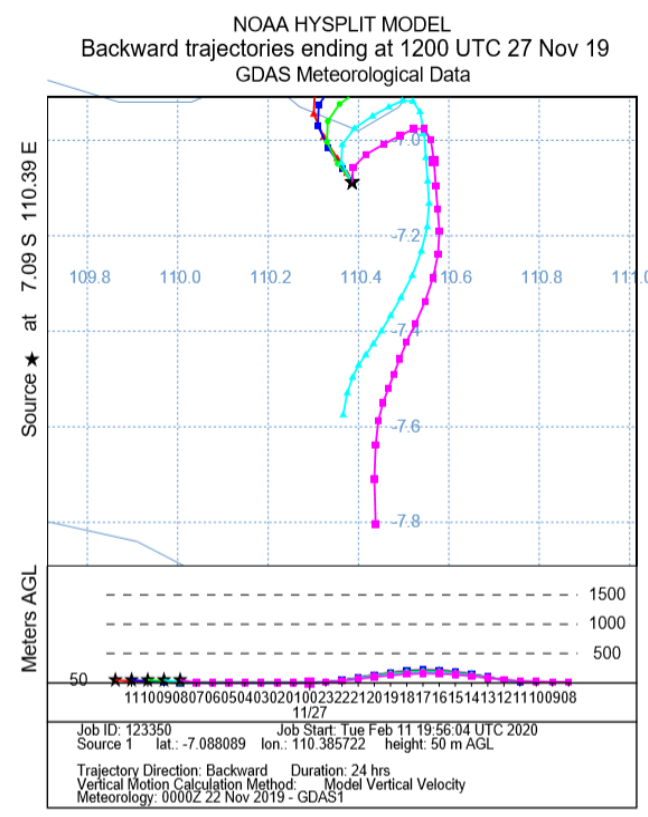

Gunungpati hari-1

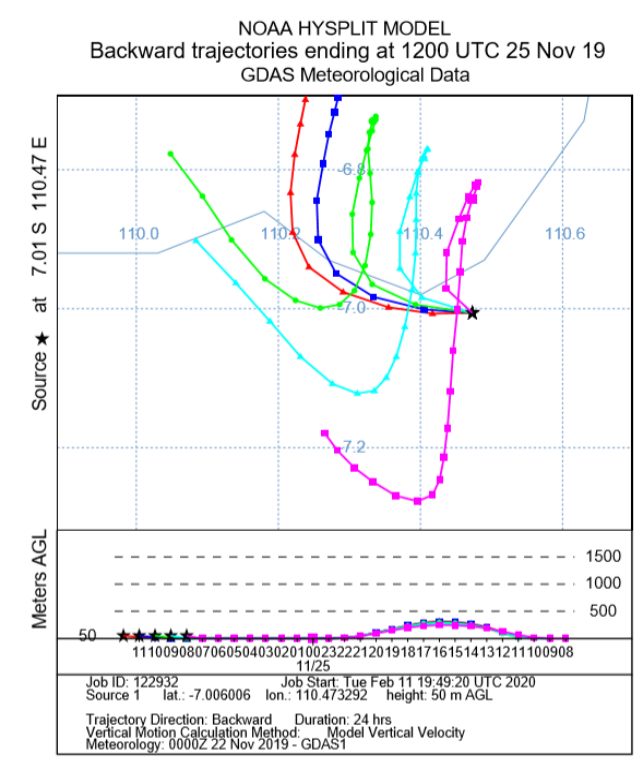

Pedurungan hari-2

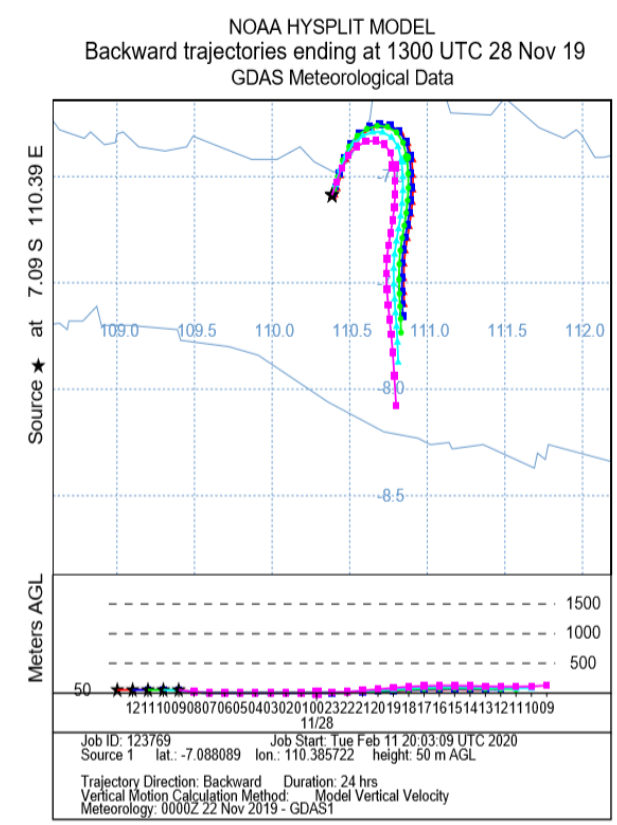

Gunungpati hari-2

Gambar 5. Lintasan balik sumber polutan di Pedurungan dan Gunung Pati Sumber: Analisis Penulis dengan model HYSPLIT 
Gambar 5 merupakan hasil analisis HYSPLIT, digunakan 5 lintasan dengan warna yang berbeda yang menggambarkan jam mulai yang berbeda - beda untuk mengetahui lintasan pada jam tersebut dengan jam akhir yang sama yaitu pada waktu pukul $10.00 \mathrm{WIB}$, hal ini untuk dilakukan untuk memvalidasi lintasan yang terjadi sehingga diketahui sumber polutannya. Ketinggian yang digunakan yaitu $50 \mathrm{~m}$ yang dianggap dapat mewakili polutan pada urban sites dalam hal ini Kota Semarang.

Dari Gambar 5 juga diketahui lintasan polutan di Kecamatan Pedurungan hari ke-1 berasal dari utara Kota Semarang yang akan berputar menuju selatan sampai dengan daerah Jawa Timur yang berakhir pada pantai selatan yang dapat menandakan sumber polutan $\mathrm{Cl}^{-}$yang dapat berasal dari aerosol laut dikarenakan tiga lintasan dari analisis HYSPLIT tersebut sampai di titik pantai selatan. Sumber polutan yang berasal dari area Kota Semarang diperkirakan berasal dari Kecamatan Tugu, Kecamatan Semarang Barat, Kecamatan Semarang Utara, Kecamatan Semarang Tengah, Kecamatan Semarang Timur, dan Kecamatan Candisari. Pada hal ini terdapat lintasan yang melewati kawasan industri seperti PT. Industri Power yang berada di Kecamatan Semarang Utara ataupun Kawasan Industri Candisari di Kecamatan Candisari. Sumber polutan tersebut juga berpotensi berasal dari kawasan permukiman penduduk dikarenakan pada google earth lintasan melewati Kecamatan Gajahmungkur dan Kecamatan Banyumanik yang dapat menghasilkan polutan dari aktivitas transportasi (hari ke-2). Perbedaan pola trajectori di Pedurungan hari ke-2 kemungkinan karena variabel meteorologi yang berbeda jauh. HYSPLIT sangat sensitif terhadap resolusi data meteorologi vertikal dan horizontal [15].

Berbeda dengan trajectori di Pedurungan, lintasan polutan di Gunungpati pada hari-1, kelima lintasan tersebut cenderung memiliki arah dan gerak yang sama yaitu berasal dari selatan menuju utara lalu belok ke barat dan berakhir bergerak ke selatan di Kecamatan Gunungpati. Gerak lintasan tersebut memiliki bentuk yang sama hingga dapat diketahui potensi sumber polutan yang tidak jauh dari satu lintasan dengan lintasan lainnya yang semuanya berakhir di Kota Magelang dan Kota Salatiga. Diketahui bahwa potensi sumber polutan area Semarang berasal dari Kecamatan Tugu, Kecamatan Ngaliyan, Kecamatan Mijen, Kecamatan Semarang Barat, Kecamatan Semarang Utara, Kecamatan Banyumanik, Kecamatan Candisari dan Kecamatan Pedurungan. Diketahui bahwa terdapat tiga lintasan yang melewati Kecamatan Tugu dan Kecamatan Ngaliyan, diketahui bahwa pada Kecamatan Tugu terdapat Kawasan Industri Wijaya Kusuma dan Kecamatan Ngaliyan terdapat Kawasan Industri Tambak Aji yang dapat berpotensi menghasilkan sumber polutan.

Backward trajectories di Kecamatan Gunungpati hari ke -2 berasal dari arah selatan lalu menuju utara, terjadi belokan ke arah barat dan berakhir di selatan yaitu Kecamatan Gunungpati. Lintasan ini melewati beberapa kecamatan seperti Kecamatan Pedurungan dan Kecamatan Banyumanik yang merupakan kawasan padat penduduk dikarenakan aktivitas manusia yang banyak menggunakan tranpsortasi sehingga berpotensi menjadi sumber pencemar. Selain itu lintasan ini juga melewati kecamatan - kecamatan yang terdapat industri di dalamnya seperti Kecamatan Genuk yang terdapat industri PLTU yang menggunakan batu bara sehingga dapat menjadi sumber polutan seperti $\mathrm{SO}_{2}, \mathrm{NO}_{3}{ }^{-}$ karena menggunakan bahan bakar fosil dan pembakaran tinggi.

\section{Kesimpulan}

Dari hasil penelitian dapat disimpulkan bahwa konsentrasi debu berkisar $60-90 \mu \mathrm{g} / \mathrm{Nm}^{3}$ dengan kandungan anion dibawah $25 \%$. Konsentrasi water soluble anion pada udara ambien di Kota Semarang yang diwakili oleh daerah Kecamatan Pedurungan dan Gunungpati untuk ion $\mathrm{F}^{-}$sebesar 0,059-0.106 $\mu \mathrm{g} / \mathrm{m}^{3}, \mathrm{Cl}^{-}$sebesar 2,29-4,08, untuk $\mathrm{NO}_{3}{ }^{-}$sebesar 4,7 - 6,53 $\mu \mathrm{g} / \mathrm{m}^{3}$ dan ion $\mathrm{SO}_{4}{ }^{2-}$ sebesar 5,2 - 7,56 $\mu \mathrm{g} / \mathrm{m}^{3}$. Sumber polutan dan lintasan di Kota Semarang pada tanggal $23-28$ November 2019 menurut aplikasi dan permodelan HYSPLIT pada ketinggian 50 m pada Kecamatan Pedurungan dan Gunungpati berasal dari daerah Selatan kecuali pada hari ke-2 di Pedurungan dimana aerosol berasal dari kawasan Utara. Dari analisis sumber diestimasi sumber polutan di Pedurungan dan Gunungpati berasal dari aktivitas industri (kawasan industri), aktivitas transportasi dan aerosol laut.

\section{Referensi}

[1] S. Smith, J. Aardenne, Z. Klimont, R.J. Andres, A. Volke and A. Delgado, Anthropogenic Sulfur Dioxide Emissions:1850-2005, Atmos. Chem. Phys. vol 11, pp. 1101-1116, 2011.

[2] B. Svedova, M. Kucbel, H. Raclvaska, J. Ruzickova, K. Raclavsky, and V, Sassamanova, "Water Soluble Ions in Dust Particles Depenting on Meteorologial Condition in Urban Environment", J.Environ.Manage. vol 237, pp. 322-331, 2019 
[3] G.-Ch, Fang, S.-Ch, Lin,S.-Y, Chang, Ch.-Y, Lin, Ch.-C.K, Chou, Y.-J, Wu, Y.-Ch, Chen, W.-T, Chen, and T.-L, Wu, "Characteristics of major secondary ions in typical polluted atmospheric aerosols during autumn in central Taiwan,". J.Environ.Manage. vol 92, pp. 1520-1527, 2011

[4] Z. Ningning, C. Junji, L. Siuxin, Z. ZhuZi, X. Hongmei and X. Shun, "Chemical composition and sources of $\mathrm{PM}_{2.5}$ and TSP collected at Qinghai Lake during summertime," Atmos.Res. vol 138, pp.213-222, 2014

[5] X. Wen, L. Xuejun, L. Lei, D.J. Anthony, T. Aohan, W. Qinghua, Z. Yangyang, H. Tianxiang, P. Yuepeng, C. Jianmin, and Z. Fusuo, "Impact of Emission Controls on Air Quality in Beijing during APEC 2014: Implications from water-soluble ions and carbonaceous aerosol in PM2.5 and their precurcors," Atmos.Environ. vol 210, pp. 241-252, 2019

[6] B. Pranamika, B. Nivedita, B. Sabrina, G. Dhatiri, B. Sudakshina, K. Manish, P. Sarma, R. Kali; Hoque, and Raza, "Spatial and Seasonal Variations of Water Soluble Ions in PM10 of MidBrahmaputra Plain of Assam Valley," Asian J. Water, Environ. Pollut. vol. 13, pp. 69-81, 2016

[7] A. F. Stein; R. R. Draxler; G. D. Rolph; B. J. B. Stunder; M. D. Cohen; F. Ngan., "NOAA's HYSPLIT Atmospheric Transport and Dispersion Modeling System. Bull. Amer. Meteor. Soc., vol 96, pp.2059-2077, 2015

[8] S. Liu, M. Hu, S. Slanina, L.Y. He, Y. Niu, E. Bruegem ann, T. Gnauk and H. Herrmann, "Size distribution and source analysis of ionic compositions of aerosols in polluted periods at Xinken in Pearl River Delta (PRD) of China," Atmos.Environ.vol 42, pp. 6284-6295, 2008

[9] BPS, Kota Semarang Dalam Angka 2017.BPS Kota Semarang. Katalog : 1102001.3374

[10] X. Yun, and L. Cong-Qiang, "Chemical characteristics of water-soluble components TSP over Guiyang SW China 2003," Atmos Environ, vol 38, pp.6297 - 6306, 2004.

[11] J.C. Chow, J.G. Watson, H. Kuhns, V. Etyemezian, D.H. Lowenthal, D. Crow, S.D. Kohl, J.P., Engelbrecht and M.C. Green, "Source profiles for industrial, mobile, and area sources in the Big Bend Regional Aerosol Visibility and Observational study," Chemosphere, vol 54, pp. 185-208, 2004

[12] W. Barbara, K. Iwona, and B. Ewa, 2012, "Fluoride pollution of atmospheric precipitation and its relationship with air circulation and weather patterns (Wielkopolski National Park, Poland)," Environ. Monit.Assess. vol 185, pp. 5497-514, 2013

[13] Y.Cheng, G.Zheng, C.Wei, Q. Mu, B. Zheng, Z. Wang, M. Gao, Q.Zhang, K.He, K.B., G.Carmichael, U. Poschl, H. Su, "Reactive nitrogen chemistry in aerosol water as a source of sulfate during haze events in China". Sci.Adv.1601530 e1601530

[14] F. Ngan, A Stein, D.Finn, R Eckman. "Dispersion simulations using HYSPLIT for the Sagebrush Tracer Experiment”. Atmos.Environ, vol 186, pp. 18-31, 2018

[15] L.Su, Z Yuan, J C.H.Fung, A.K.H.Lau, "A comparison of HYSPLIT backward trajectories generated from two GDAS datasets. Sci Total Environ, vol 506-507, pp. 527-537, 2015 